\title{
補綴診療の立場から見た医療費
}

\section{岩崎 庄市}

\section{Medical Fees for Prosthetic Treatment}

\section{Shoichi Iwasaki $i^{*, * * * * *}$}

The practicing dentist faces a large number of difficulties in operating his clinic today. In particular, economic constraints have become quite serious, and are causing considerable difficulties in clinical operations.

This deterioration in the operating environment has its origin in the fact that the remuneration for medical treatment is being carried out as a controlled economy in a capitalist economic system. Although it is only common sense that necessary operating expenses be covered by income, this fact has not been acknowledged in the medical community.

Although the Ministry of Health and Welfare has detrmined that dentists are receiving adequate compensation based on their surveys of medical practice operations, there is no surplus to permit a reliable profit while including necessary expenses for the dentists who is burdened with daily clinical practice and the acquisition of rapidly progressing knowledge in the field of dentistry.

As practicing dentists, we must publicize our actual operating conditions by carrying out cost calculations based on accurate data, and endeavor to obtain appropriate remuneration. In this discussion I would like to clarify this situation from this point of view, by carrying out cost calculations for an actual clinical case.

\section{A. 歯科医療管理学と歯科医療費}

人間社会における種々の職種 (Profession) は, そこに住む人達の要求によって生ずる。なかで も，医療は疼痛および死への恐怖とそれを排除し

\footnotetext{
* 北九州市八幡東区開業

** 九州霜科大学非常勤講師

*** 九州大学歯学部非常勤講師

日本顎咬合学会誌
}

ようとする本態に基づく人間最大の要求から生ず る基本的な職種の一ついえる。そこに医療が Liberal Profession として社会に高い評価をらけ るゆえんがあり，また，本質的な人間性が要求さ れる側面も生じてくる。現在，医師側では医療の 質が問題にされ，患者側からは医師のモラルが疑 われている現実は，医療のもつ本質的代人間的な 側面と医師の置かれた経済的側面とのジレンマ 
が，いかに解決困難な問題であるかを浮きぼりに しているょうである。

ところで，歯科医師に 対する 社会の要求は何 か，その基礎となるのは歯科医学であろう．FDI では歯学を次のように定義している.

Dentistry-The science and art of preventing, diagnosing and treating of diseases and malformations and injuries to the teeth, jaws and mouths and of replacing lost teeth and associated tissues.

また，歯科医師法では歯科医師の任務を次のよ らに定めている。

歯科医師法第一条：歯科医師は，歯科医療扣よ び保健指導を掌ることによって，公衆衛生の向上 扣よび増進槣与し，もって国民の健康な生活を 確保するものとする。

上記の歯科医学と歯科医療は互いに単独に存在 しても社会の要求に応ずることはできないもので あり，それが理論と実践として合致することによ ってのみ目的が達成されるものである，かかる観 点から歯科医学の社会的発展の場を考えると，

Home dental health care

Professional dental health care

Public dental health care の三つの場があり，なかでも90数\%の歯科医師が 関与する場は Professional D.H.C. である. しか しこれが行われる歯科診療所では，それが生業と いら形であるために，歯科医学・医術をストレー トに適用し得ない事情がある。かかる場に関連す る事項の解明に，歯科医療管理学の果たすべき役 割がある。

すなわち，歯科医師が診療を通じて歯学を患者 に応用する場合の応用上の諸問題を対象とするの が歯科医療管理学であり, 質の良い, 高度の歯科 医療をできるだけ広い階層の人達に及ぼすことを 目的とし, 医学部門と経営部門との均衡を保つこ とを考慮しつつ歯科医学を実践に移寸手法を考究 する学問であるとされている。また，これの実践 にあたっては，医療管理の三面等価の原則が適用 される。

医療管理の実践においては，人格を底辺とし， 医学的要素と経営学的要素の両辺が互に交ってで

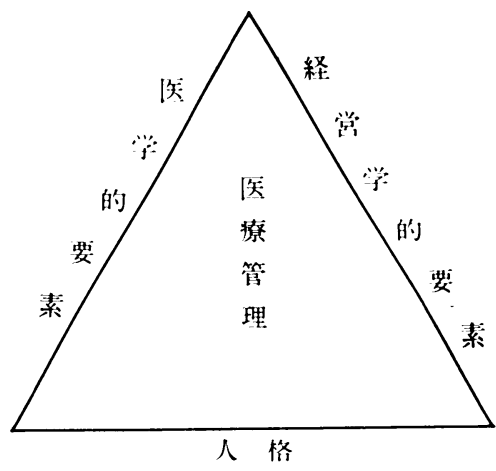

図 1

きる正三角形で表わされる三面等価の原則にのっ とって行われるべきである.

わが国に括ける来科医療の実態に打いて，果し てこの三辺が等長で均衡ある正三角形のもとに医 療管理が行われているであろらかといら疑念は払 拭し得ないものがある。

かつて，日本歯科医師会が歯科医業経営の理念 として，歯科医院に扣ける利益目的を述べたこと がある。

すなわち，医院は利益なくして永続はない 医院は利益なくして安定はない 医院は利益なくして発展はない 医院は利益なくして社会への奉仕は できない

以上四項目を今一度見直したいと考えるもので ある。

\section{B. 歯科診療報酬の適正評価に関する実験的 考察}

本論文は昭和 51 年に福岡県歯科医師会において 作成されたものであるが，本稿に打ける記述はそ の一部を抜粋し，かつ，それを基礎としてデータ を新しくしたものである.

\section{1. 考察の基硴となる臨床例のとり方}

わが国の社会保険は，大正11年にドイツのビス マルク強制社会保険にみられた国家理論を背景と した,社会政策としての性格をもって制定された。 
これが社会保障的見地より考虑されたのは，敗戦 による新憲法第25条の制定を契機とするものであ

り，国民の最低限生活確保の目的のために，貧困 に対する公的扶助々低所得階層に対する社会福祉 と相俟って，貧困化の予防対策としての社会保険 という形で体系づけられた。このような理念に拉 ける社会保障体系は, ベバリッジ構想を基本とす るものであり，国家に対して生活保障を要求する 新しい思想としてのナショナル・ミニマムという 概念の一般化であると同時に資本主義が高度に発 展した段階に扣いて, 増大寸る社会不安や生活上 の危機に対処するための国家的姿勢であった。 そ の後, 昭和30年代後半から始った日本経済の高度 成長と，それによってもたらされた豊かな社会の 出現と昭和36年の皆保険・皆年金の実施に伴う社 会保障をめぐる動向や社会環境の変化などが，こ の理念と実態との間に齕噛を生ぜしめ,さらに現 在, 経済の高度成長が伸び悩み, 人口老齢化がも たらす人口構造の変化が急速に進みつつあること により，医療保障体系はより大きな抜本的指向転 換を迫られている。

かかる医療保険の時代的推移を勘案し，21世紀 の医療保障の道を開く鍵は, 制度の改革や保険財 政のなかにではなく，医療現場にこそあることを 十分に認識しなければならない。医療現場に扣い て，医師や歯科医師が適正な医療を行うべきこと が，もっとも基本となるべきであり，すべての問 題がここから出発しなければならない。すなわ ち, 現行歯科医学のもとで, 歯科医師としてなさ ねばならぬ要件を満たす医療であり，少なくとも 医原性疾患を起こさないことを最低条件とした医 療が行える環境が整うことである.

このような観点から, 本稿执いては, 補経診 療の立場からという前提で, 現行社会保険に基づ き, 初診から鋳造冠装着までの臨床例を選んで基 礎データを作成し，それによって論を進めていき たいと考えた，診療行為の範囲は，可及的に広く する見地から, 単独する行為ではなく, 関連する 医療行為の複合する形として考慮した。 その理由 は, 医療行為というものは部分的に成立してもそ の疾患を治癒せしめ得なければ価值がないという 性格をもつからである。
表 1
D：歯科医師
A : 歯科助手
$\mathrm{H}$ ：歯科衛生土
$\mathrm{T}$ : 歯科技工士

\begin{tabular}{c|c|c}
\hline 処 置 名 & 担 当 & 所要時間 \\
\hline スタディモデル & $\mathrm{D}$ & 5 分 \\
印象・製作 & $\mathrm{H}$ & 10分 \\
& $\mathrm{T}$ & 20 分 \\
\hline
\end{tabular}

\section{2. 臨床例のデータの種類}

データの収集は 8 名の歯科医師によって行い, 得られた結果は一同の評議の対象となり, 過半数 が納得し得ないデータや問題となった医療行為に ついては，再度あるいは再三にわたる追試による 確認の形をとることによって標準性と妥当性を高 めた。また，これを多数の歯科医師から得られた 診療結果の平均としなかった理由は, その医療行 為についての責任を問ら立場からであり，そのた めに平均的な結果を得ることについては最大限の 努力を払った。

データ表には，処置に対する担当者，その担当 者がそれぞれの処置に要した時間，その処置のた めに消費した材料名とそのメーカー扣よび包装価 格を示し，その価格から使用数量に対する所要費 用を算出した。 このデータ表には略称を使用した 部分や, 単位数量のとり方について解説を行った 方が分りやすい部分があるためにそれらについて 以下に記する。

1) 担当者

2) 所要時間

表1は, スタディモデルの印象と製作に関し て, 歯科医師が 5 分, 歯科衛生土が 10 分, 歯科技 工土が20分，それぞれに時間を要したということ である。この場合の所要時間は，すべて実働時間 をとって扣り，模型製作の際の石膏硬化時間や， 鋳造に打けるワックス焼却時間など, いわゆる待 時間に類するものは含まれていない。

3) 消耗品名

使用消耗品については, 純粋な品名を記入した ものと, 常識的に判明できる範囲で商品名を記入 したものとがある。

\section{4) メーカー}

診療券などのように, 各個に歯科医院が印刷所 
に発注して製作するようなものについては, 自家 製といら記入方法にした。

\section{5 ) 使用数量}

単位として使用したものについて，その使い方 を記すると，

枚：何枚あるいは，何分の何枚といら記入にし た。

個：同様に何個あるいは，何分の何個とした，

本：ガッタパーチャポイントやインレーワック スなどのように, 本数がはっきりしているものに ついては, 何本とか何分の何本とかの記入とした.

注射針やバー，ポイント類，ダウェルピンなど のように，分割できないものを $1 / 3$ 本とか， $1 / 10$ 本と表示しているものがあるが，これは 1 本を 3 回使用することができるとか，1本を10回使用で きると仮定して，などの意味をもって扣り，リー マーファイル $12 / 5$ 本ということは, リーマーファ イルを12本組みとして, 平均 5 回使用に耐えると いらことである。またタービンバー $1 / 12$ 本 $\times 4$ と あるのは, 12回分使用できるバー（1回 5 分使用 として 1 時間）を各種類 4 本使用したといらこと である.

$\mathrm{ml}, \mathrm{cc}, \mathrm{cm}, \mathrm{m}, \mathrm{g}, \mathrm{kg}$ : これらについては, 実際 使用量を測定して記入したが, 実測不能なものに ついては文献による確認を行った。 また，パラク リーン $20 / 4 \mathrm{cc}$ とか, モデリング60/3 g とあるの は $20 \mathrm{cc}$ のパラクリーンを 4 回, $60 \mathrm{~g}$ のモデリン グを 3 回使用できたという意味を示している.

$\mathrm{Tab}$ : 何錠使用したかを個数で示した.

管：カートリッヂ注射液については何管といら ことにした.

歯分：自家製銅線を個人ポスト製作用に使用す る際などは，1歯分の単位で算出した。

回分：レントゲン現象液などは総量を何カ月で 消費し，その間に何枚のレントゲンを現像するか によって1回分の所要量を算出した. 同じように セップスプレーやダイセップなども全量から 1 回 の使用量を算出した。

使用分：モデルスプレーやワックスパターンク リーナーなどはその総量を何カ月で使用し，1日 にどれ位の模型やハィターンを製作するかによっ て，その使用量を決定した。

\section{3、データを作成した臨床例}

\section{1 ) 診療内容}

本症例は， 1 歯科医師の個人診療所に来院した 31歳の女性の左側下顎第 1 大目雨のう蝕 3 度急性 化膿性歯髄炎を対象とし, その初診行為から鋳造 冠装着までの一連した医療行為にもとづくデータ である。

2）診療条件扣よび診療上の留意点

本症例は, 雬科診療が顎・口腔単位によってな されるべきであるとする考え方に立って，計画診 療の診療形態をとった。これは口腔内諸器官の調 和のもとに診療効率と効果を高める方法であり, そのためには，万触予防指導や診療上の助言・相 談などのコミュニケーションが基本的に必要であ った。

治療は注射麻酔による拔㭪有を行い, 根管長測定 はルートキャナルメーターを使用し，加圧根充を 行った。

築造体は根管内に維持を求めるため, シリコー ン印象材で印象を行い，銀合金で製作した。築造 体の装着後に支台雨形成を行い，雨肉縁の保護と 咬合関係を維持するため当日に即重レジンで作製 した暫間クラウンを装着して㷌宅させた。

鋳造冠の製作は，残存歯の歯列扣よび咬合関係 がほぼ正常であったので, 全顎印象を行わずに局 部印象を行い, 多少とも顎運動にマッチさせるた め F.G.P. テクニックを用い，機能コアーを作製

して蠟形の彫刻を行った。

最終的な調整を行らために，口腔内にて仮着を 行い，2 日後に来院させて咬合関係を修正したら えでセメントで装着した。

3）診療録とデータ表

\section{表 $2 \sim 7$}

\section{4. 歯科医療行為の原価計算}

通常の場合, 価格決定については, 適正な原価 計算方法にもとついて算出した原価に，適正な利 潤を加えて算出される。製造工業において生産さ れた製品は，その製造過程に扮いて発生した原価 を基礎として，それに販売費および管理費を加え て合計した総原価を，製造数量で除することによ って，単位数量当たりの原価を算定する。 
表 2

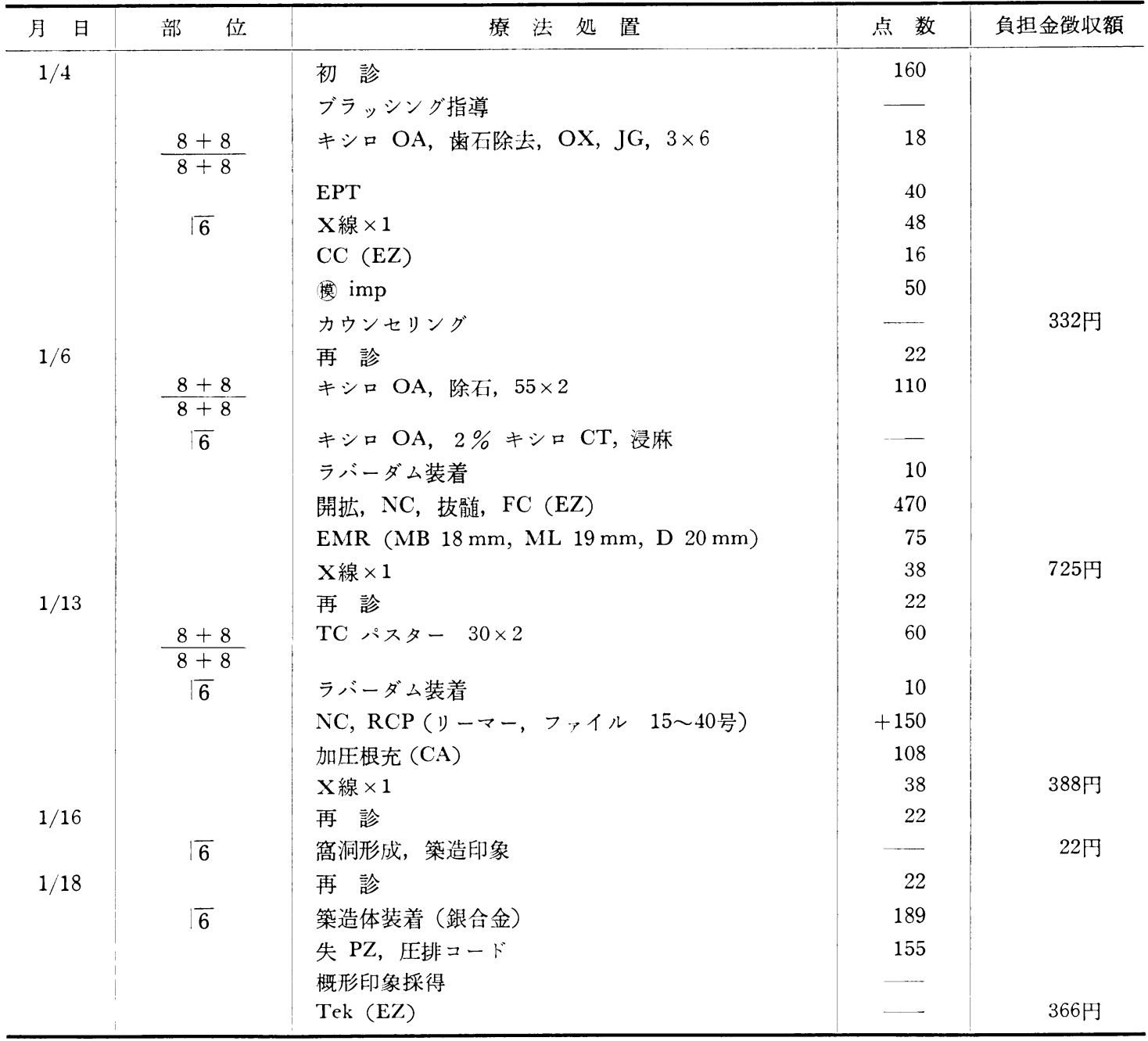

表 3

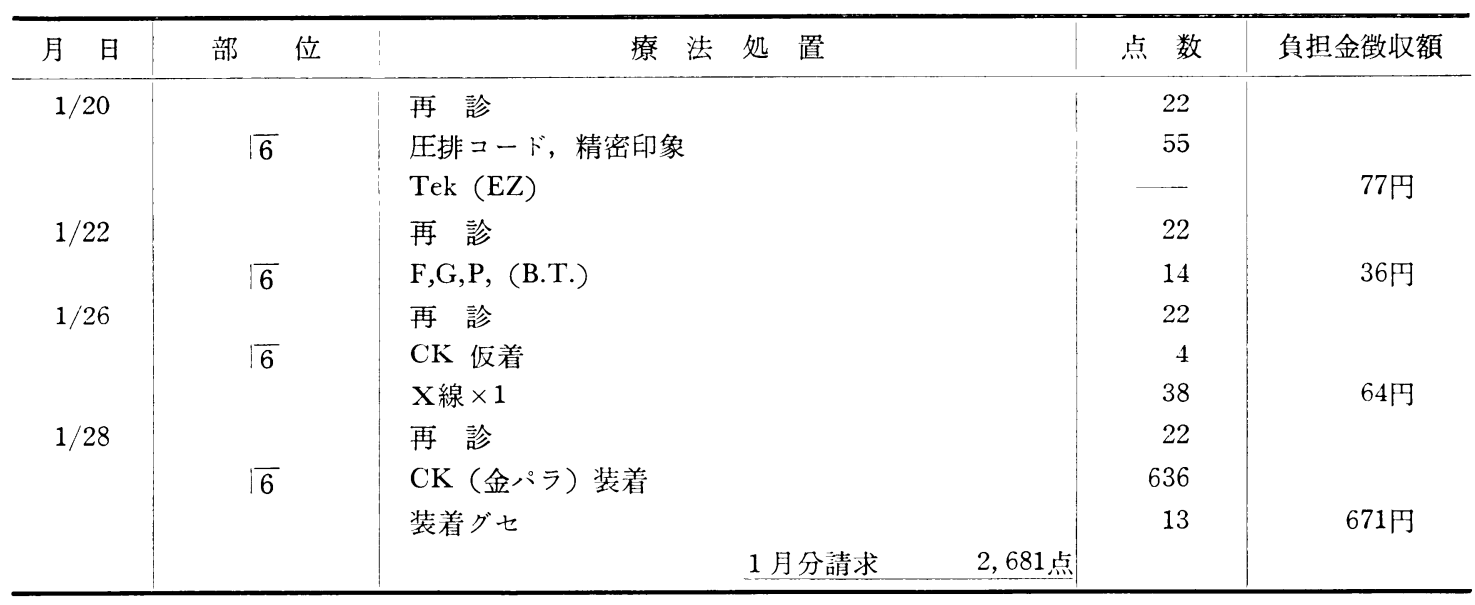


表 4

\begin{tabular}{|c|c|c|c|c|c|c|c|}
\hline 処 置名 & 担 & $\begin{array}{l}\text { 所要 } \\
\text { 時間 }\end{array}$ & 使用消耗品名 & メーカー & $\begin{array}{l}\text { 包装価格 } \\
\text { (円) }\end{array}$ & 使用数量 & $\begin{array}{l}\text { 所 要 } \\
\text { 費 用 }\end{array}$ \\
\hline 受 付 & $\begin{array}{l}\mathrm{A} \\
\mathrm{H}\end{array}$ & $\begin{array}{l}5 \text { 分 } \\
15 \text { 分 }\end{array}$ & $\begin{array}{l}\text { 予 診 表 } \\
\text { 診 察 券 } \\
\text { カ ル テ } \\
\text { 請求明細書 } \\
\text { アポイントメントブック }\end{array}$ & $\begin{array}{l}\text { 福岡県歯科医師会 } \\
\text { 自 家 製 } \\
\text { 福岡県歯科医師会 } \\
\text { 福岡県歯科医師会 } \\
\text { 自 家 製 }\end{array}$ & $\begin{array}{rr}50 \text { 枚 } & 85 \\
500 \text { 枚 } & 5,000 \\
50 \text { 枚 } & 90 \\
50 \text { 枚 } & 70\end{array}$ & $\begin{array}{r}1 \text { 枚 } \\
1 \text { 枚 } \\
1 \text { 枚 } \\
1 \text { 枚 } \\
\text { 使用分 }\end{array}$ & $\begin{array}{l}2 \text { 円 } \\
10 \text { 円 } \\
2 \text { 円 } \\
1 \text { 円 } \\
4 \text { 円 }\end{array}$ \\
\hline $\begin{array}{l}\text { ブラッシソグ指 } \\
\text { 導および歯石除 } \\
\text { 去 }\end{array}$ & $\mathrm{H}$ & 50 分 & $\begin{array}{l}\text { カラーテスター } \\
\text { キシロカイン表面麻酔 } \\
\text { デンタルフロス }\end{array}$ & $\begin{array}{l}\text { サンスター } \\
\text { 藤沢薬品 } \\
\text { ジョンソンェンド } \\
\text { ジョンソン }\end{array}$ & $\begin{array}{c}200 \mathrm{Tab} 600 \\
80 \mathrm{~g} \quad 5,160 \\
200 \mathrm{Y} 1,020 \\
(182.8 \mathrm{~m})\end{array}$ & $\begin{array}{l}2 \mathrm{Tab} \\
1 \mathrm{~g} \\
1.2 \mathrm{~m}\end{array}$ & $\begin{array}{l}6 \text { 円 } \\
65 \text { 円 } \\
7 \text { 円 }\end{array}$ \\
\hline $\begin{array}{ll}\mathrm{X} \text {-ray 撮 } & \text { 影 } \\
\text { 現 像 }\end{array}$ & $\mathrm{D}$ & 3 分 & $\begin{array}{l}\text { レントゲンフィルム } \\
\text { レントゲン現像液 }\end{array}$ & $\begin{array}{l}\text { 阪神技術研究所 } \\
\text { 阪神技術研究所 }\end{array}$ & $\begin{array}{lr}100 \text { 枚 } & 3,250 \\
\text { 1液 } & 250 \\
2 \text { 液 } & 250\end{array}$ & $\begin{array}{l}1 \text { 枚 } \\
1 \text { 回分 }\end{array}$ & 19円 \\
\hline $\begin{array}{l}\text { スタディモデル } \\
\text { 印象・製作 }\end{array}$ & $\begin{array}{l}\mathrm{H} \\
\mathrm{A} \\
\mathrm{T}\end{array}$ & $\begin{array}{l}10 \text { 分 } \\
5 \text { 分 } \\
25 \text { 分 }\end{array}$ & $\begin{array}{l}\text { アローマ DF II } \\
\text { サンエスグリーン }\end{array}$ & $\begin{array}{l}\text { ジーシー } \\
\text { サンェス }\end{array}$ & $\begin{array}{l}5 \mathrm{~K} \quad 21,200 \\
18 \mathrm{~kg} \quad 8,900\end{array}$ & $\begin{array}{r}40 \mathrm{~g} \\
170 \mathrm{~g}\end{array}$ & $\begin{array}{l}\text { 170円 } \\
\text { 84円 }\end{array}$ \\
\hline 歯䯣電気検査 & $\mathrm{D}$ & 8 分 & & & & & \\
\hline 単純治療 & $\begin{array}{l}\mathrm{D} \\
\mathrm{A}\end{array}$ & $\begin{array}{l}8 \text { 分 } \\
8 \text { 分 }\end{array}$ & $\begin{array}{l}\text { フェノールカンフル } \\
\text { ユージノールセメント }\end{array}$ & $\begin{array}{l}\text { 日本歯科薬品 } \\
\text { 昭和薬品 }\end{array}$ & $\begin{array}{c}15 \mathrm{~m} l 2,600 \\
\text { 七ット } 6,400 \\
(\text { 散 } 50 \mathrm{~g})\end{array}$ & $\begin{array}{r}0.04 \mathrm{ml} \\
\text { 散 } 0.6 \mathrm{~g}\end{array}$ & $\begin{array}{l}7 \text { 円 } \\
77 \text { 円 }\end{array}$ \\
\hline カウンセリング & $\mathrm{D}$ & 25 分 & & & & & \\
\hline $\begin{array}{l}\text { 拔髄および根管 } \\
\text { 払大 }\end{array}$ & $\begin{array}{l}\mathrm{D} \\
\mathrm{A}\end{array}$ & $\begin{array}{l}50 \text { 分 } \\
50 \text { 分 }\end{array}$ & $\begin{array}{l}\text { カートリッヂ針 } \\
\text { キシロカインカートリッ゙ } \\
\text { ラバーダム用ラバー } \\
\text { タービン用バー } \\
\text { エンジン用バー } \\
\text { ピーソーリーマー } \\
\text { リーマー・ファイル } \\
\text { レントゲンフィルム } \\
\text { レントゲン現像液 } \\
\text { クレンザー } \\
\text { ブローチ } \\
\text { ネオクリーナー } \\
\text { ホルマリンクレゾール } \\
\text { ユージノールセメント }\end{array}$ & $\begin{array}{l}\text { 藤沢薬品 } \\
\text { 藤沢薬品 } \\
\text { コロンバス } \\
\text { ジーシー } \\
\text { エラ } \\
\text { メルファー } \\
\text { マイクロメガ } \\
\text { 阪神技術研究所 } \\
\text { 阪神技術研究所 } \\
\text { ピア ス } \\
\text { ピア ア } \\
\text { ネオ製薬 } \\
\text { 日本幽科薬品 } \\
\text { 昭和薬品 }\end{array}$ & $\begin{array}{cr}100 \text { 本 } & 2,500 \\
1.8 \mathrm{~m} l \times 50 \\
& 4,900 \\
36 \text { 枚 } & 2,200 \\
\text { 長 } & 1,500 \\
\text { 短 } & 750 \\
6 \text { 本 } & 600 \\
6 \text { 本 } & 3,600 \\
6 \text { 本 } & 2,000 \\
100 \text { 枚 } & 3,250 \\
1 \text { 液 } & 250 \\
2 \text { 液 } & 250 \\
6 \text { 打 } & 4,790 \\
6 \text { 打 } & 3,980 \\
30 \mathrm{~m} l & 1,200 \\
15 \mathrm{~m} l & 2,600 \\
\text { 七ッ卜 } & 6,400 \\
(\text { 散 } & 50 \mathrm{~g})\end{array}$ & $\begin{array}{c}1 \text { 針 } \\
1.8 \mathrm{~m} l \\
1 \text { 管 } \\
1 \text { 枚 } \\
1 / 12 \text { 本 } \times 2 \\
1 / 3 \text { 本 } \times 2 \\
1 / 10 \text { 本 } \\
12 \text { 本 } \\
1 \text { 枚 } \\
1 \text { 回分 } \\
1 \text { 本 } \\
3 \text { 本 } \\
0.3 \mathrm{~m} l \\
0.1 \mathrm{~m} l \\
\text { 散 } 0.6 \mathrm{~g}\end{array}$ & $\begin{array}{r}25 \text { 円 } \\
98 \text { 円 } \\
61 \text { 円 } \\
188 \text { 円 } \\
67 \text { 円 } \\
60 \text { 円 } \\
4,000 \text { 円 } \\
33 \text { 円 } \\
19 \text { 円 } \\
67 \text { 円 } \\
166 \text { 円 } \\
12 \text { 円 } \\
17 \text { 円 } \\
77 \text { 円 }\end{array}$ \\
\hline 根管長測定 & $\mathrm{D}$ & 16分 & & & & & \\
\hline 根管充填 & $\begin{array}{l}\mathrm{D} \\
\mathrm{A}\end{array}$ & $\begin{array}{l}30 \text { 分 } \\
30 \text { 分 }\end{array}$ & $\begin{array}{l}\text { ラバーダム用ラバー } \\
\text { レンツロ }\end{array}$ & $\begin{array}{l}\text { コロンバス } \\
\text { メルファー }\end{array}$ & $\begin{array}{rr}36 \text { 枚 } & 2,200 \\
4 \text { 本 } & 2,000\end{array}$ & $\begin{array}{l}1 \text { 枚 } \\
1 \text { 本 }\end{array}$ & $\begin{array}{r}\text { 61円 } \\
515 \text { 円 }\end{array}$ \\
\hline
\end{tabular}


表 5

\begin{tabular}{|c|c|c|c|c|c|c|c|}
\hline 処 置 名 & $\begin{array}{l}\text { 担 } \\
\text { 当 }\end{array}$ & $\begin{array}{l}\text { 所要 } \\
\text { 時間 }\end{array}$ & 使用消耗品名 & メーカー & $\begin{array}{c}\text { 包装価格 } \\
\text { (円) }\end{array}$ & 使用数量 & $\begin{array}{c}\text { 乺 要 } \\
\text { 費 }\end{array}$ \\
\hline 根管充填 & & & $\begin{array}{l}\text { キャナルス } \\
\text { ガッタパーチ+ポイント } \\
\text { エリートセメント } \\
\text { レントゲンフィルム } \\
\text { レントゲン現像液 }\end{array}$ & $\begin{array}{l}\text { 昭和薬品 } \\
\text { ジーシー } \\
\text { ジーシー } \\
\text { 阪神技術研究所 } \\
\text { 阪神技術研究所 }\end{array}$ & \begin{tabular}{|c|} 
七ット 8,500 \\
(散 $15 \mathrm{~g}$ ) \\
150 本 2,670 \\
七觉 4,470 \\
(梏 $125 \mathrm{~g}$ ) \\
100 枚 3,250 \\
1 液 250 \\
2 液 250
\end{tabular} & $\begin{array}{l}\text { 散 } 0.3 \mathrm{~g} \\
6 \text { 本 } \\
\text { 末 } 1.5 \mathrm{~g} \\
1 \text { 枚 } \\
1 \text { 回分 }\end{array}$ & $\begin{array}{r}170 \text { 円 } \\
107 \text { 円 } \\
54 \text { 円 } \\
33 \text { 円 } \\
19 \text { 円 }\end{array}$ \\
\hline $\begin{array}{l}\text { 䆚洞形成 } \\
\text { 築造体製作 } \\
\text { Tek 製作 }\end{array}$ & $\begin{array}{l}\mathrm{D} \\
\mathrm{A} \\
\mathrm{T}\end{array}$ & $\begin{array}{l}20 \text { 分 } \\
20 \text { 分 } \\
80 \text { 分 }\end{array}$ & $\begin{array}{l}\text { アローマDF II } \\
\text { レンッロ } \\
\text { バイトワックス } \\
\text { ストッピング } \\
\text { セメント } \\
\text { 咬合 紙 } \\
\text { 普通石膏 } \\
\text { インレーワックス } \\
\text { スプルーチューブ } \\
\text { ワックスパターン } \\
\text { シュールキャストスプレー } \\
\text { ユニファスト } \\
\text { アクロヒップ } \\
\text { 埋 没 材 } \\
\text { アスベストリボン } \\
\text { ミロブライト } \\
\text { 結 㷊 線 } \\
\text { カーボランダムポイント } \\
\text { ペー゚ーューン } \\
\text { シリコンポイント }\end{array}$ & $\begin{array}{l} \\
\text { ジーシー } \\
\text { メルフ } \\
\text { ジーシー } \\
\text { ジーシー } \\
\text { ジーシー } \\
\text { ジーシー } \\
\text { SSS } \\
\text { ジーシー } \\
\text { 大栄歯科産栐 } \\
\text { ジーシー } \\
\text { ジーシー } \\
\text { ジーシー } \\
\text { ジーシー } \\
\text { ジーシー } \\
\text { ジーシー } \\
\text { ジーシー } \\
\text { モ リ タ } \\
\text { 松 風 } \\
\text { 晴 光 社 } \\
\text { ジーシー }\end{array}$ & \begin{tabular}{|cc|}
1 本 & 1,500 \\
10 本 & 1,300 \\
$\mathrm{H} \cdot \mathrm{B}$ & $1.5 \mathrm{~kg}$ \\
& 6,420 \\
$\mathrm{I} \cdot \mathrm{J}$ & $160 \mathrm{~g}$ \\
& 4,820 \\
$5 \mathrm{~K}$ & 21,200 \\
4 本 & 2,000 \\
$250 \mathrm{~g}$ & 2,160 \\
$500 \mathrm{~g}$ & 6,800 \\
七ット & 3,500 \\
120 枚 & 1,260 \\
$18 \mathrm{~kg}$ & 8,700 \\
60 本 & 2,700 \\
30 本 & 2,000 \\
$100 \mathrm{~g}$ & 1,800 \\
\multicolumn{3}{|c|}{} \\
$150 \mathrm{~g}$ & 1,900 \\
七ット & 15,500 \\
(兴 & $250 \mathrm{~g})$ \\
$300 \mathrm{~g}$ & 1,540 \\
$3 \mathrm{~kg}$ & 4,200 \\
$10 \mathrm{~m}$ & 2,100 \\
$100 \mathrm{mg}$ & 14,600 \\
$100 \mathrm{~g}$ & 1,700 \\
1 打 & 1,450 \\
100 個 & 1,600 \\
1 打 & 1,750
\end{tabular} & $\begin{array}{c}20 \mathrm{~g} \\
1 \text { 本 } \\
1 / 5 \text { 枚 } \\
0.5 \mathrm{~g} \\
3 \mathrm{~g} \\
1 / 2 \text { 枚 } \\
90 \mathrm{~g} \\
1 / 5 \text { 本 } \\
1 / 7 \text { 本 } \\
\text { 使用分 } \\
0.2 \mathrm{~g} \\
0.5 \mathrm{~g} \\
\text { 使用分 } \\
80 \mathrm{~g} \\
10 \mathrm{~cm} \\
3 \mathrm{~g} \\
40 \mathrm{~cm} \\
1 / 20 \text { 本 } \times 2 \\
2 \text { 個 } \\
1 / 10 \text { 本 } \times 2\end{array}$ & 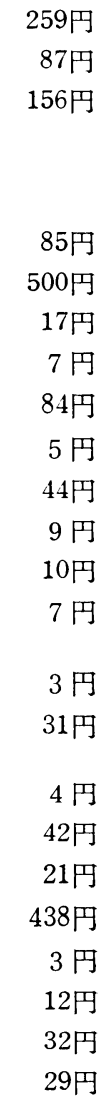 \\
\hline 製造体装着 & $\mathrm{H}$ & $\begin{array}{l}15 \text { 分 } \\
5 \text { 分 }\end{array}$ & $\begin{array}{l}\text { エリートセメント } \\
\text { 咬合 紙 } \\
\text { カーボランダムポイント } \\
\text { シリコンポイント }\end{array}$ & $\begin{array}{l}\text { ジーシー } \\
\text { ジーシー } \\
\text { 松 風 } \\
\text { 松 風 }\end{array}$ & 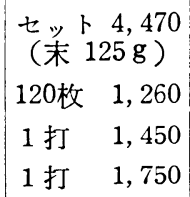 & $\begin{array}{l}1.5 \mathrm{~g} \\
1 / 2 \text { 枚 } \\
1 / 20 \text { 本 } \\
1 / 10 \text { 本 }\end{array}$ & $\begin{array}{l}54 \text { 円 } \\
5 \text { 円 } \\
6 \text { 円 } \\
15 \text { 円 }\end{array}$ \\
\hline
\end{tabular}

製造工業の場合,

基礎原価

直接原材料費

+)

直接賃金

直接経費

間接原材料費

間接顀金

日本罘咬合学会誌 


\begin{tabular}{|c|c|c|c|c|c|c|c|}
\hline 処 置 名 & $\begin{array}{l}\text { 担 } \\
\text { 当 }\end{array}$ & $\begin{array}{l}\text { 所要 } \\
\text { 時間 }\end{array}$ & 使用消耗品名 & メーカー & $\begin{array}{c}\text { 包装価格 } \\
\text { (円) }\end{array}$ & 使用数量 & $\begin{array}{l}\text { 所 要 } \\
\text { 費 角 }\end{array}$ \\
\hline $\begin{array}{l}\text { 支台歯形成 } \\
\text { Tek 装着 } \\
\text { 概形印象採得 } \\
\text { 精密印象採得 } \\
\text { (機能コア) }\end{array}$ & $\begin{array}{l}\mathrm{D} \\
\mathrm{A} \\
\mathrm{T}\end{array}$ & $\begin{array}{l}70 \text { 分 } \\
30 \text { 分 } \\
40 \text { 分 }\end{array}$ & $\begin{array}{l}\text { ハイトワックス } \\
\text { ブルーワックス } \\
\text { 咬合 紙 } \\
\text { カッパーバンド } \\
\text { パラクリーン } \\
\text { サンプラロー } \\
\text { 嗍 砂 } \\
\text { トレーレジンII } \\
\text { パラフィンワックス } \\
\text { 結 禁 線 } \\
\text { 硬 石 亭 } \\
\text { 普通石高 } \\
\text { ユニファスト }\end{array}$ & 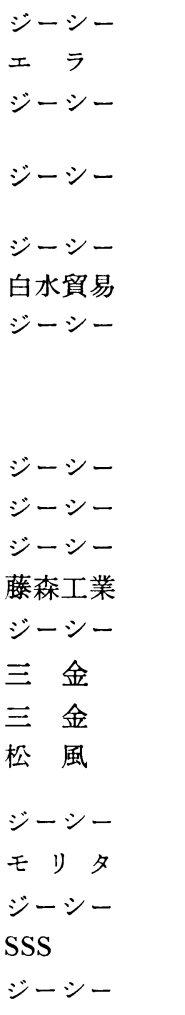 & 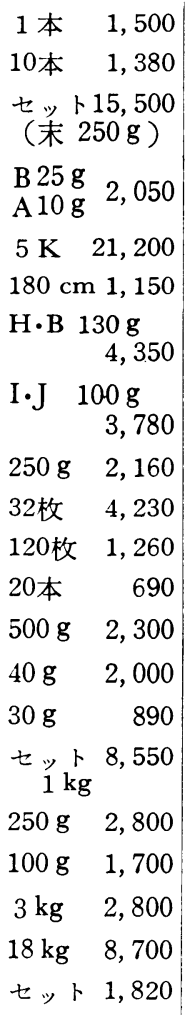 & $\begin{array}{c}1 / 12 \text { 本 } \times 2 \\
1 / 3 \text { 本 } \times 2 \\
\text { 末 } 0.3 \mathrm{~g} \\
0.5 \mathrm{~g} \times 3 \\
20 \mathrm{~g} \times 2 \\
5 \mathrm{~cm} \\
20 \mathrm{~g} \\
5 \mathrm{~g} \\
2 \mathrm{~g} \\
1 / 20 \text { 枚 } \\
1 / 2 \text { 枚 } \\
1 \text { 本 } \\
20 / 4 \mathrm{cc} \\
0.01 \mathrm{~g} \\
\text { 使用分 } \\
\text { 末 } 10 \mathrm{~g} \\
2 \mathrm{~g} \\
70 \mathrm{~cm} \\
60 \mathrm{~g} \\
20 \mathrm{~g} \\
\text { 末 } 1 \mathrm{~g}\end{array}$ & 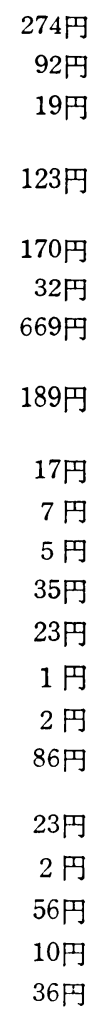 \\
\hline 作業模型製作 & $\mathrm{T}$ & 20 分 & $\begin{array}{l}\text { 超硬石膏 } \\
\text { 普通石膏 } \\
\text { 硬 石 膏 } \\
\text { ダウェルピン } \\
\text { 結 紮 線 }\end{array}$ & $\begin{array}{l}\text { ジーシー } \\
\text { 日東石膏 } \\
\text { ジーシー } \\
\text { 村上研究所 } \\
\text { モリ タ }\end{array}$ & $\begin{array}{cc}2.25 \mathrm{~kg} & 3,400 \\
18 \mathrm{~kg} & 8,700 \\
3 \mathrm{~kg} & 2,800 \\
10 \text { 本 } & 2,000 \\
100 \mathrm{~g} & 1,700\end{array}$ & $\begin{array}{r}20 \mathrm{~g} \\
50 \mathrm{~g} \\
20 \mathrm{~g} \\
1 / 10 \text { 本 } \\
60 \mathrm{~cm}\end{array}$ & $\begin{array}{l}30 円 \\
24 円 \\
17 円 \\
20 円 \\
3 \text { 円 }\end{array}$ \\
\hline
\end{tabular}

間接経費

製造原価

+)

販売費扣よび管理費

総原価

商業の場合は, 単位数量当たりの原価を算定す ることはまれで，一般に期間売上高に対する期間 売上原価を算定し, 売上高から売上原価を控除す ることによって，売上利益を算定する。

商業の場合,

期首棚卸高
+ )

当期仕入高

$$
-)
$$

期末棚卸高

売上原価

+ )

販売費および管理費

総原価

となる。

採算計算の見地から，もっとも一般的に使用さ れる原価は総原価である。総原価に適正利潤を加 


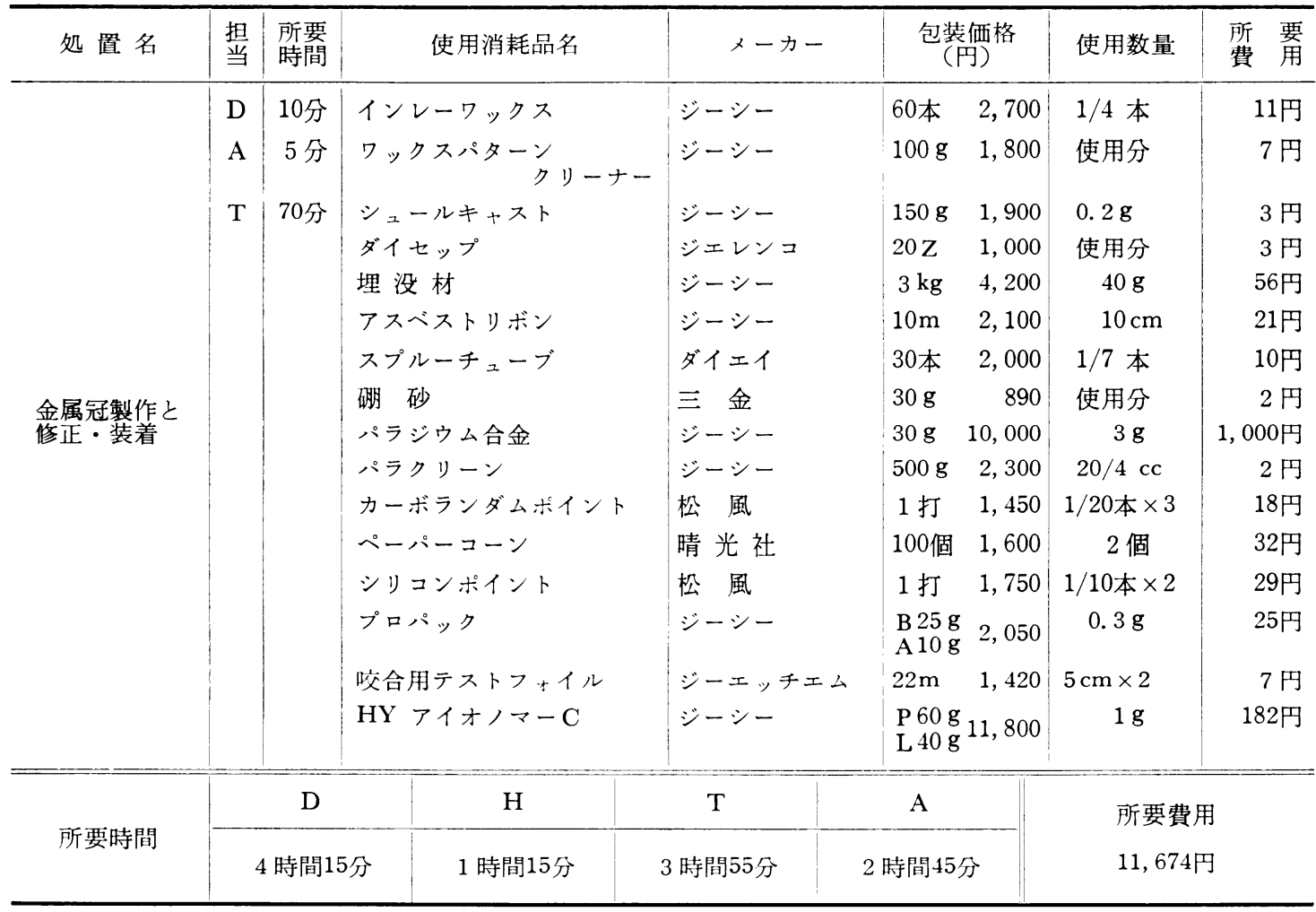

えることによって，価格が形成される。ただし， この場合に問題となるのは，それぞれ個々の企業 の条件によって，同一の製品であっても，原価が 異ってくることである，たと爷ば，操業度が高く なれば，総原価としての単位原価は低くなるし， また操業度が低くなれば, 単位原価は逆に高くな ってくる。したがって，一定の操業度をもって， 価格決定の資料としての総原価を計算しなければ ならないし，この操業度を一定の率として計算さ れた総原価としての単位原価をもって，価格決定 の基礎とすることが望ましいということである.

原価は操業度との関係に扣いて, 変動費（直接 費）之固定費（間接費）に分解される，变動費は 操業度の变化に応じて変動し, 固定費は操業度の 変化にかかわりなく発生する原価をいう。

これを生産数量との関係に扣いて見れば，変動 費は生産数量の変化にかかわりなく単位当たりに ついて一定であり，固定費は生産数量が増加する

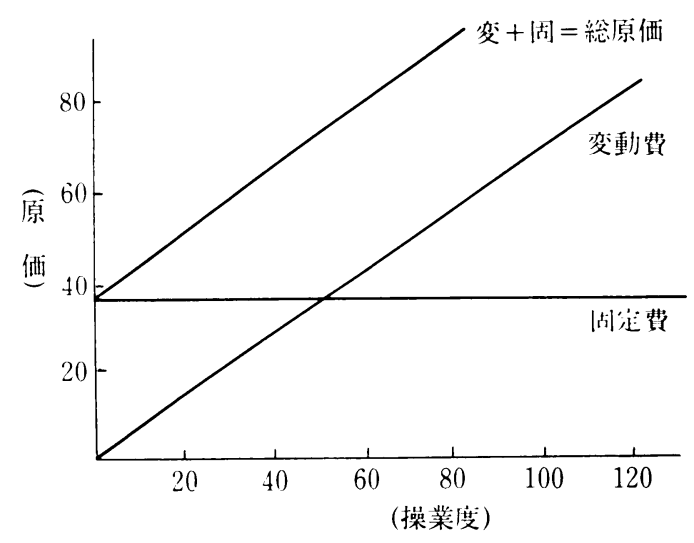

図 2 単位原価と操業度

ほど少なくなる。

歯科医療費の算定は，その性格上，製造工業の 原価計算方法に準じて考兄られるべきであろら． したがって，原価計算にあたっては，基礎原価， 診療原価，診療総原価を計上しなければならない 


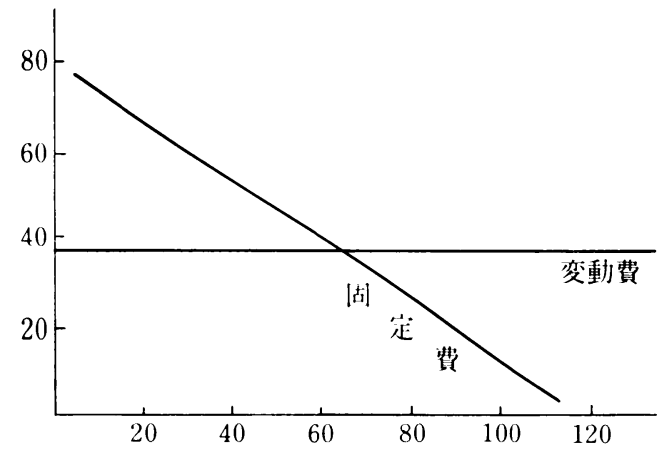

図 3 原価之操業度

ことになる。すなわち，

(1) 基礎原価

$\left\{\begin{array}{l}\text { 主要材料費 } \\ \text { 直接消耗品費 } \\ \text { 貢金 }(\text { 所要時間 } \times \text { 貢率) }\end{array}\right.$

2) 診療原価

$\left\{\begin{array}{l}\text { 基礎原価 } \\ \text { 診療諸経費 (所要時間 } \times \text { 負担率) }\end{array}\right.$

(3) 㟝療総原価

診療原価

病院維持管理費 (所要時間 $\times$ 負担率)

となる。

この原価計算方式について，とくに考慮されな ければならないことは, 前述した操業度の問題で あり，これのとり入れ方いかんによっては，単位 原価がまったく異ってくることである。この操業 度について，雨科医療の場合には，受診患者数を とるか，歯科医師の労働時間数をとるかのいずれ かによることが適当であろらと考えられる。一般 の企業の場合には, 生産数量か売上高をもって操 業度の指標とするが，歯科医院の場合は，すべて の受診患者が霜科医師と診療補助者の手を煩わす ところからみて, 量的, 質的の両面の観点から歯 科医師などの労働時間 (実労働)をもって操業度 の指標とするのが妥当であろらと思惟される.

(1) 基礎原価

(2) 基礎原価 + 診療諸経費 $=$ 診療原価

(3) 診療原価 + 病院維持管理費 $=$ 診療総原価 の順序で原価を算定し，それに適正利潤を加えて 価格の決定を行うことが望ましい. しかし, 採算

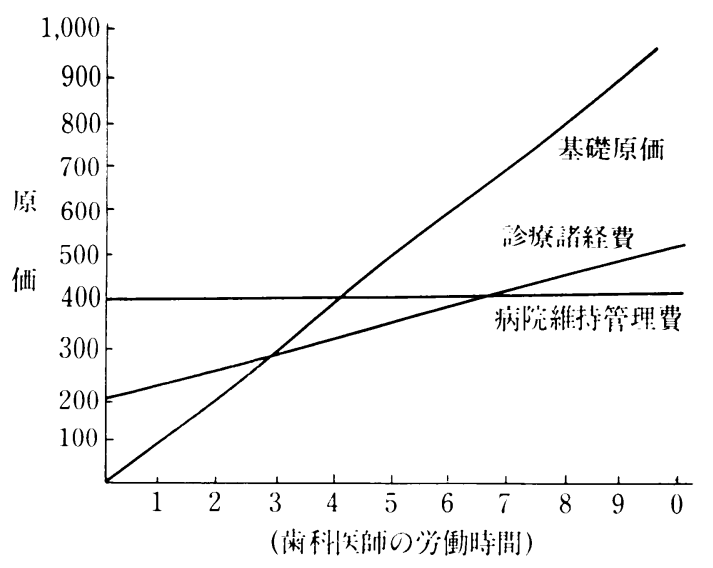

図 4 歯科医療原価の構成要素

計算が先行する企業と異り，質的充実が優先する 医療では人的関与が多く，賃金が原価構成要素に 拈いて大きな比率を占めるところから，賃金を中 心とする原価の算定方法をとることがより合理的 であろらと思われる。

\section{5. 原価計算の実際}

原価計算の実際にあたっては，標準原価を計算 し，それを基礎とする方法がとられる．標準原価 とは，ある特定の医療行為について標準的モデル を設定し，それに必要な原価を計算集計するもの である．設定されたモデルについての原価のうち 変動費については原価計算が割合に容易である が，固定費については困難な問題が生ずる．固定 費は操業度（治療所要時間）の增減によって, 時 間当たりの負担割合が異ってくるからである。す なわち，1日の治療所要時間を何時間にするかが 問題である。医療は他の事業と異り，人命に関す るものであり，絶対にミスが許されない作業行為 であり，乙かも高度の知識にもとづく判断的要素 が大部分であることからみて，これに他事業と同 じ感覚で労働時間数を設定することは，本来不適 当であるとしなければならない，かかる要件など を考慮しながら以下の算定方法を行った。

標準原価による診療総原価の算定方法

（1）標準消費数量 $\times$ 標準単価 $=$ 標準主要材料 消耗品費

（2）標準所要時間 $\times$ 標準賃率 $=$ 標準貨金 
表 8

\begin{tabular}{c|c|r|r|c}
\hline 職 種 & 給 与 (円) & 賞 与 (円) & 退職金 (円) & 年当り㑑金(円) \\
\hline 歯 科医師 & 408,822 & $2,158,580$ & $16,352,880$ & $7,609,540$ \\
歯科技工士 & 184,556 & 649,635 & $7,382,240$ & $3,110,382$ \\
歯科衛生士 & 159,924 & 562,932 & & $2,482,020$ \\
歯 科助 手 & 133,445 & 469,724 & & $2,071,064$ \\
\hline
\end{tabular}

（退職金は40カ月分として算出した）

(1) $+(2)=$ 標準基礎原価

（3）標準所要時間 $\times$ 標準経費率 $=$ 標準諸経費 (1) $+(2)+(3)=$ 標準診療原価

(4) 標準所要時間 $\times$ 標準維持管理費率 $=$ 標準 維持管理費

(1) + (2) + (3) $+(4)=$ 標準診療総原価

(1) 各項目に打忛る算定基礎数值のとり方

a.人件費

人件費については，標準賃金計算のモデルとし

て，人事院が行った“職種別民間給与実態調査” と関東経営者協会が行った “モデル退職一時金調 査”および労働省の“賃金構造基本統計調查”を 参考にして算出した。

b. 年間労働 (診療) 時間数

表 9 は, 年間を通して一般歯科診療所に扣いて 行われる診療時間のモデル設定表である。この表 では年間に 2,120 時間の労働時間が示されてい る.しかし，すでに大企業に打いてはもちろん， 官公署に扣いても週休 2 日制が採用され，学校教 育の場にもこれが及ばんとする今日である。ま た，前述したとおり医療職に扎いては心身両面の 緊張が強いられることが多く，一般職に打ける場 合よりも以上に労働時間が考慮されなければなら ない事情や，日進月歩の医学知識を吸収しなけれ ば真の医療を行うことができない面なども存在し ている.

このような見地から，表 9 が診療時間を 8 時間 としているのは改善されてしかるべきであり,1日 の実際診療時間は 6 時間程度に設定するのが妥当 であろら.かかる理由により, 年間労働時間数を,

240 日 $\times 6$ 時間 $=1,440$ 時間

50 日 $\times 4$ 時間 $=200$ 時間

$$
\text { 合計 } 1,640 \text { 時間 }
$$

表 9 年間労働時間数

\begin{tabular}{c|r|c}
\hline 䜒療時間 & 日 数 & 総時間数 \\
\hline 全日診療 (8 時間) & 240 日 & $1,920 \mathrm{hr}$ \\
半日診療 (4 時間) & 50 日 & $200 \mathrm{hr}$ \\
日 祭 日 & 64 日 & 0 \\
休 診 日 & 11 日 & 0 \\
\hline
\end{tabular}

とした。

c 。年間の診療諸経費と病院維持管理費

診療諸経費と病院維持管理費については，その 診療行為当たりや 1 日当たりの費用を算出するこ とは困難である。そのため本考察に拈いては所得 税確定申告書の青色申告決算書に必要経費として あげられたものを基礎として算出した。しかし， これらの費用は個別性が強く，標準值が奈辺にあ るか推測し難い．本稿に拈いては可能な範井に抏 いて推測すべく，申告書の記載が確実であろうと 思われる雨科医師に可及的ご協力を頂き平均值を 算出した。なお，この算出にあたっては，かけ離 れて数値の高いものや低いものについては平均値 を乱す要素であるとして計算から除外した。

(2)貝率と経費率と維持管理費率

a 。人件費に拈ける賃率計算は

$\frac{\text { 標準支払給与 }}{\text { 標準治療時間数 }}=$ 標準賃率

であるから，

柬科医師は，

$$
\begin{aligned}
& \frac{7,609,540 \text { 円 }}{1,640 \text { 時間 }}=4,640 \text { 円 分当たり } \frac{4,640 \text { 円 }}{60 \text { 分 }} \\
& =77 \text { 菜 }
\end{aligned}
$$

隶科技工士は,

$$
\begin{aligned}
& \frac{3,110,382 円}{1,640 \text { 時間 }}=1,897 \text { 分当たり } \frac{1,897 \text { 円 }}{60 \text { 分 }} \\
& \quad=32 \text { 円 }
\end{aligned}
$$


表 10

\begin{tabular}{|c|c|c|c|c|c|}
\hline & 目 & 金 額 (円) & & 科 & 金 額 (円) \\
\hline \multirow{8}{*}{$\begin{array}{l}\text { 診 } \\
\text { 療 } \\
\text { 諸 } \\
\text { 経 } \\
\text { 費 }\end{array}$} & 水道光熱費 & 818,772 & \multirow{8}{*}{$\begin{array}{l}\text { 病 } \\
\text { 徖 } \\
\text { 篗 } \\
\text { 䈕 } \\
\text { 費 }\end{array}$} & 旅費交通費 & 821,840 \\
\hline & 損害保険料 & 437,172 & & 通 信 費 & 367,835 \\
\hline & 修 繥 費 & 162,036 & & 四書研究費 & $2,214,139$ \\
\hline & 消耗品費 & 252, 983 & & 衛生管理費 & 426,664 \\
\hline & 減価消却費 & $1,394,752$ & & 諸 会 費 & $1,421,804$ \\
\hline & 福利厚生費 & $2,568,355$ & & 雑 & 335,573 \\
\hline & 租税公課 & 370,645 & & 地代家貨 & $1,090,104$ \\
\hline & 合 計 & $6,004,715$ & & 合 計 & $6,677,959$ \\
\hline
\end{tabular}

歯科衛生士は,

$$
\begin{aligned}
& \frac{2,482,020 \text { 円 }}{1,640 \text { 時間 }}=1,513 \text { 円 分当たり } \frac{1,513 \text { 円 }}{60 \text { 分 }} \\
& =25 \text { 率は }
\end{aligned}
$$

歯科助手は,

$$
\begin{aligned}
& \frac{2,071,064 \text { 円 }}{1,640 \text { 時間 }}=1,263 \text { 円 分当たり } \frac{1,263 \text { 円 }}{60 \text { 分 }} \\
& \quad=21 \text { 菜 }
\end{aligned}
$$

b 。診療諸経費率は

$\frac{\text { 年間標準診療諸経費 }}{\text { 年間標準治療時間数 }}=$ 標準診療諸経費率

であるから,

$\frac{6,004,715 \text { 円 }}{1,640 \text { 時間 }}=3,661$ 分当たり $\frac{3,661 \text { 円 }}{60 \text { 分 }}$

$$
=61 \text { 円 }
$$

c 。病院維持管理費率は

年間標準病院維持管理費 $=$ 標準病院 年間標準治療時間数 $=$ 維持管理費率

であるから,

$\frac{6,677,959 \text { 円 }}{1,640 \text { 時間 }}=4,072$ 分当たり維持

$$
\frac{4,072 \text { 円 }}{60 \text { 分 }}=68 \text { 円 }
$$

となる。

(3.モデル症例に扣ける診療総原価の算定

a . 直接原材料消耗品費

直接消耗品費

賃金

$$
\begin{array}{lr}
\text { 歯科医師 } & 255 \text { 分 } \times 77 \text { 円 }=19,635 \text { 円 } \\
\text { 歯科衛生士 } & 75 \text { 分 } \times 25 \text { 円 }=1,875 \text { 円 } \\
\text { 歯科技工士 } & 235 \text { 分 } \times 32 \text { 円 }=7,520 \text { 円 } \\
\text { 歯科助手 } & 165 \text { 分 } \times 21 \text { 円 }=3,465 \text { 円 }
\end{array}
$$

（1）基礎原価

44, 169円

\section{b 。䧐療諸経費}

診療諸経費にかかる所要時間は, この症例の場 合，歯科医師と歯科衛生士はそれぞれ個々の分野 に拈いて別個に医療行為を行うものであるから， それぞれの所要時間の合計とする.

$$
(255 \text { 分 }+75 \text { 分 }) \times 61 \text { 円 }=20,130 \text { 円 }
$$

$$
\text { (1) }+ \text { (2) 診療原価 } 64,299 \text { 円 }
$$

c 。病院維持管理費

診療諸経費と同様に両者の所要時間を合計して 維持管理費率を乗ずる。

$$
\begin{aligned}
& (255 \text { 分 }+75 \text { 分 }) \times 68 \text { 円 }=22,440 \text { 円 } \\
& (1)+(2)+(3) \text { 診療総原価 } 86,739 \text { 円 }
\end{aligned}
$$

4. 社会保険報酬亡診療原価の比較

本考察に扣いて設定したモデル症例を対象に保 険診療を行ったところ，総原価が保險診療報酬の 3 倍を超える結果となった。

(5) その他の臨床例に拈けるデータ

昭和51年に行った“雪科診療報酬の適正評価に 関する実験的考察”に扔いては，前述のケースの 外に, 膿漏, 充填, 継続雨, 架工義歯, 義歯などに ついてのデータを作成した。 方法は本稿で報告し た症例と全く同梯である，以下それらについて， 参考として，データのみを報告する。

\section{C. 適正な歯科医療費とは}

いささか古い資料であるが，図 5 は昭和 51 年 3 月から59年 4 月にわたって日本歯科医師会調查室 が行った調査のデータであり，実線より上の網目 
表 11

\begin{tabular}{c|c|c|c|c|c|c|c}
\hline \multirow{2}{*}{ 保険点数 (点) } & 金 $\begin{array}{c}\mathrm{A} \\
\text { 額 (円) }\end{array}$ & 基礎原価(円) & 診療原価(円) & 診療総原価(円) & $\mathrm{A}-\mathrm{B}$ & $\mathrm{B} / \mathrm{A}$ \\
\hline 2,681 & 26,810 & 44,169 & 64,299 & 86,739 & $-59,929$ & 3.2 \\
\hline
\end{tabular}

表 12

\begin{tabular}{|c|c|c|c|c|c|c|c|}
\hline 症 例 & 保険点数 & (A) 額 & 基礎原価 & 䛦療原価 & $\begin{array}{c}\text { 診療総原価 } \\
(\text { (B) }\end{array}$ & $A-B$ & $\mathrm{~B} / \mathrm{A}$ \\
\hline A & 1,222 & 12,220 & 22,145 & 29,570 & 38,480 & $-26,260$ & 3.1 \\
\hline B & 1,284 & 12,840 & 15,472 & 19,342 & 24,040 & $-11,200$ & 1.9 \\
\hline $\mathrm{C}$ & 1,432 & 14,320 & 37,989 & 42,264 & 47,394 & $-33,074$ & 3.3 \\
\hline $\mathrm{D}$ & 911 & 9,110 & 24,787 & 28,417 & 32,773 & $-23,663$ & 3.6 \\
\hline $\mathrm{E}$ & 1,116 & 11,160 & 35,954 & 43,304 & 52,124 & $-40,964$ & 4.7 \\
\hline F & 1,047 & 10,470 & 38,456 & 47,996 & 59,444 & $-48,974$ & 5.7 \\
\hline G & 2,098 & 20,980 & 28,048 & 34,168 & 41,512 & $-20,532$ & 2.0 \\
\hline $\mathrm{H}$ & 2,420 & 24,200 & 29,802 & 34,527 & 40,197 & $-15,997$ & 1. 7 \\
\hline 合 計 & 11,530 & 115,300 & 232,608 & 279,588 & 335,964 & $-220,664$ & 2.9 \\
\hline
\end{tabular}

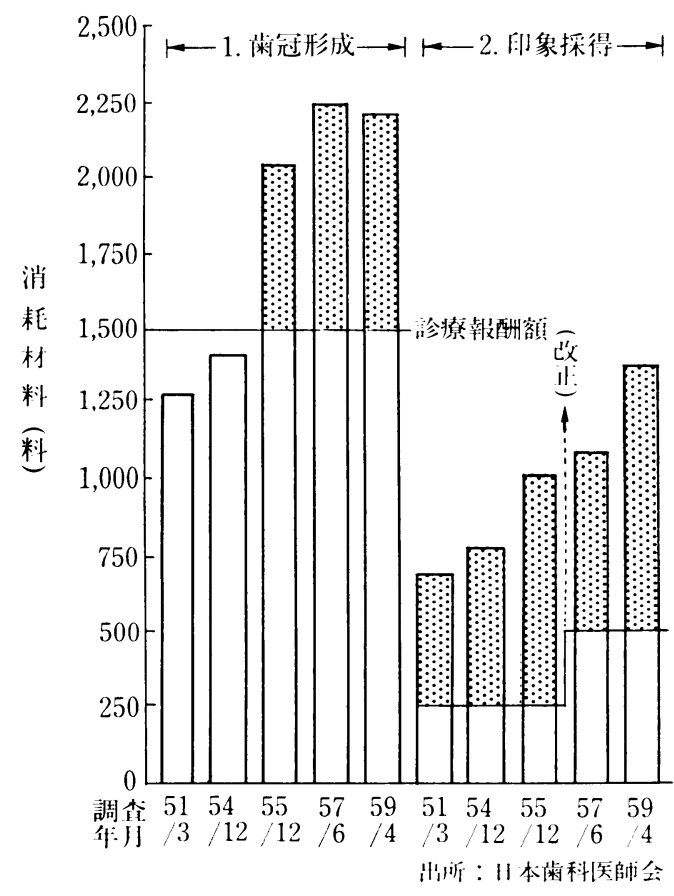

図 5 診療報酬と消耗材料との関係

の部分は，中間消耗材料が保険診療報酬を越えて いることを示している。

その他の資料をみても，わが国における保满診 日本顎咬合学会誌

\begin{tabular}{|c|c|c|c|c|}
\hline & ${ }^{11}$ 本 & $\begin{array}{c}\text { 少ドイツ } \\
\text { (1979) }\end{array}$ & $\begin{array}{c}\text { スウェーデン } \\
(1978)\end{array}$ & $\begin{array}{c}\text { 丁メリカ } \\
(197 i)\end{array}$ \\
\hline & ドイッマルク & 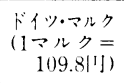 & $\begin{array}{l}\text { クロ } \\
\text { (1クロ }+ \text { - } \\
=47 \text { (1) }\end{array}$ & $\begin{array}{c}\text { U.S.ドル } \\
\text { (1ドル= } \\
\left.\left.265\right|^{1}\right)\end{array}$ \\
\hline 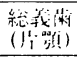 & $15.7001 \mathrm{j}$ & $63.20001 \mathrm{~J}$ & $39 .(0101011]$ & $73,940 \mid$ '] \\
\hline
\end{tabular}

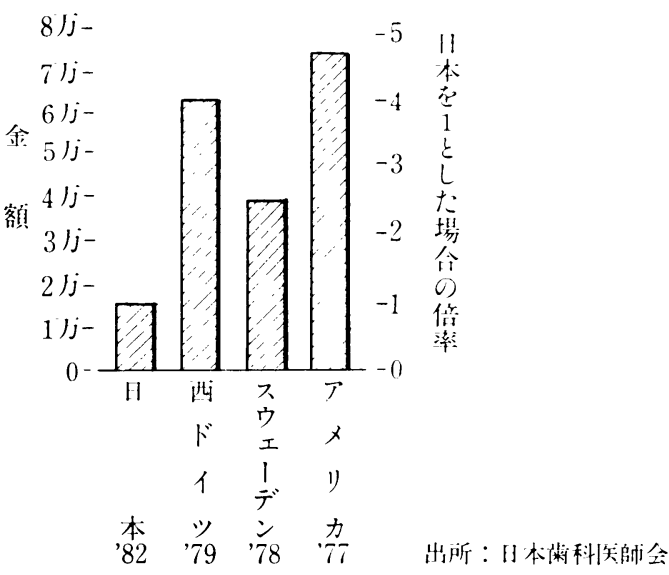

図 6 総義崡の診療報酬の国際比較

療が低医療費に抑兄られていることは歴然であ 万.

現在の資本主義制度のもとに拈いては，資本を 投下して事業を行ら場合，事業収益が付随するこ 
表 13 主な歯科診療行為の報酬の国際比較

\begin{tabular}{|c|c|c|c|}
\hline & 日本 $\left(\begin{array}{l}1981 \\
1982\end{array}\right)$ & $\begin{array}{l}\text { アメリカ } \\
(1982)\end{array}$ & $\begin{array}{c}\text { 西ドイツ } \\
\text { (1981) }\end{array}$ \\
\hline 初 診 & 1, 450円 & 2,300 円 & 1, 020円 \\
\hline $\begin{array}{l}\text { アマルガム充填 } \\
\text { ( } 3 \text { 面) }\end{array}$ & 2,920円 & 8,050円 & 3, 570円 \\
\hline $\begin{array}{l}\text { コンポジット充 } \\
\text { 填 ( } 2 \text { 面) }\end{array}$ & 2,860円 & 7, 360円 & 2,805 円 \\
\hline 全部鋳造冠 & 8,790円 & $69,000 円$ & 32,080 円 \\
\hline $\begin{array}{l}\text { レジン床総義歯 } \\
\text { (片顎) }\end{array}$ & 17,730円 & 86, 250円 & 56,185円 \\
\hline 抜 雪（日歯） & 1,700円 & 5,750円 & 2,040 円 \\
\hline 歯内療法 (3 根) & 6,750円 & 51,750円 & 17,000円 \\
\hline
\end{tabular}

出所：日本歯科医師会

とは経済の鉄則であり，それを基礎として経済活 動が活発化することは，いまさら触れるまですな いことである。しかるに，歯科医療の保険報酬汇 おいては，原価の充足さえ行われていないことは 前述したと扣りであり，いわゆるマージンと称さ れるものの評価などは全くなされていないのが実 情である

このような現状に，一般開業歯科医師がいかに 対応しているかについて，下記に歯科医院の経営 の実態を示す表を提示した。すなわち，収入金額 線 $(\mathrm{R})$ と総経費線 $(\mathrm{F}+\mathrm{V})$ が交叉する損益分岐 点 (B.E.P.) 以上の収入があれば黒字経営である が，それに達しない場合は赤字経営となるが，良 質な医療行為を行兄ば適正な損益分岐点汇達する ことができないため，固定費 $(\mathrm{F})$ や変動費 $(\mathrm{V})$ を押さえることにより $(F)^{\prime}(\mathrm{V})^{\prime}$ ，損益分岐点を 無理に下げて採算を合わせざるを得ないことにな る。これは医療の質の低下汇もつながりかねない 問題であり看過されるべきことではない。また， 診療時間をふやすことにより操業度を高め，単位 当たりの診療原価（U.C.）を下げようとする試み もあろらが，これは歯科医師の過重労働となり， ひいては適切な医療行為の妨げともなるものであ る.

（F）固定費，（V) 変動費，（R）収入金額，(F $+V$ ) 総経費, (U.C.) 単位原価, (B.E.P.) 損益分 岐点，(F)' 下方へ移動した固定費，(V)' 下方の 変動費, (B.E.P.)' 下方の損益分岐点.

診療報酬の現状は以上のと扤りであるが, 本来,

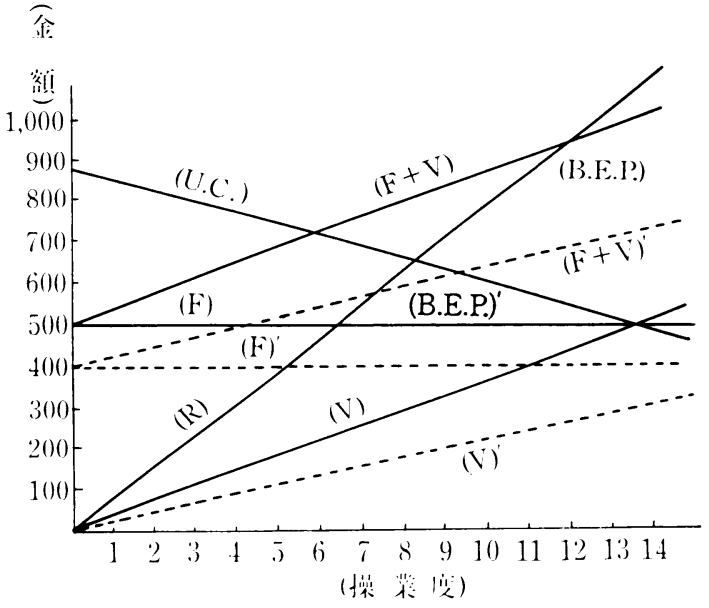

图 7

報酬という言葉には，価格という言葉より以上に 付加されたものがあるよう感じられる。広辞苑 によると，報酬とは，むくい，返礼などという意 味もあり，そこに人的関与があるとするふくみを もって招り，それが人間対人間の関係の上に成り 立っているため, 超物価的要素が強く，他の種々 な要素によって規制されるべき性格のものではな いといった考え方や，感謝に対するある種のむく いが加味されて当然であるという解釈などがなさ れる場合もある。かかる要素に関与する事項とし て，医療の特性，歯科医療の特性もある。

医療の特性

1. 医療というものはまず需要が優先する。し かし，その需要を予測して扣くことは困難であ り，仮に予測ができてもそれに対応した医療を事 前に行うことはできない。

2. 医療はきわめて個別的であって，既成で間 に合わせることができない性質のものであるか ら，どんなに機械化が進歩しても，医㞠の量産や ストックはできない.

3.どんな医療を行うかということは，医師が 医学的判断のもとに自主的に決定するものであっ て，需要側が注文して行うものではない。

4. 行った医療に関しては，患者がこれを正確 汇評価する能力がないから，診療報酬はその地域 性に基づいた物価や人件費などに対応して自律的 に決められる性格のものである。 
さらに, 歯科医療の特性は,

1. 歯科疾患には，自然治癒に期待できるもの が現状ではきわめて少ないが，反面この種の疾患 については，米科医師の助言や指導と社会の人々 の心がけ次第でかなりの程度まで予防できるとい う点がある。

2. 歯科診療に扣いては，日常行われる診療の すべての場面での手技的技量や学識が，医療効果 に大きく影響するといら大きな特性がある。

3. 重大な特性として自然治癒がないところの 実質欠損や歯牙欠損に対して，理工学的材料で修 復を行らといらことがある。

4. 修復には暫定修復と永久性修復がある。乙 かもその方法についてさらに種類があり，打の抏 のに要する経費も異なる。したがって, 修復方法 の選択については患者の意志が関与する余地があ る.

上記の他にも適正な診療報酬に関与する要素は 多小.

開業早々の歯科医と経験豊かな歯科医，一般的 な歯科医と専門を有する歯科医，それぞれに受け る報酬に違いがあってしかるべきではないかとい うことや，患者の信頼度や感謝の程度によっても 差がつくであろうということなども，それを報 酬と呼ぶ优直する要素ではなからうかということ である。そして，このような人間性というものを 内在しているとすれば，診療報酬には自由性があ り，統一とか画一とかにはなじみ難い性質を持っ ているであろらと考えられる。

しかし，いずれにせよ，医療の社会化によって 国が医療の対価に関与する現状では診療報酬を画 一化せざるを得ない事情があり，これが診療報酬 の自由性を否定する結果になっている。歯科医師 個人の学識, 経験, 技術, 倫理感や患者側の個別 の事情, 設備や立地条件の違いなどを反映させる ことが，ほとんど不可能な状態に拈ける対価体系 を報酬と呼ぶことによって生ずる多くの齟龉と誤 解が医療界を混乱させる一因ともなっていること
を，医療担当者を含めた社会全体が十分に認識し なければ医療費問題の解決は困難であろう。

\section{D. むすび}

本稿の中核としてとりあげた“医療保障制度の 改善と歯科診療報酬の適正評価汇関する実験的考 察” は, 前述のと扣り昭和51年に福岡県歯科医師 会において作られた論文であるが，この考察の端 緒となった動機は, 昭和51年 1 年11月に NHK テ レビで放映された“みんなで語ろう・歯医者さん” といら番組であった。われわれが国民歯科医療の 担当者として, 低医療費の健康保険のもとで, ど のように苦しみ悩んでいるか，その実態がわかっ て鿓觉ないせつない気持からの出発であった。 そ の後福岡県歯科医師会の事業の一環としてとりあ げられ，さらに，日本歯科医師会の委託事業とい う恵まれた形で進展した。 その間, 数々の力強い 声援もあった。同業である歯科医師はもちろんで あるが，専門外の方々からも，「歯医者さんはこ んなに苦しい実態をどうしてもっとはっきり公表 しないんだ.」という扣叱りを受けたりもした。 この資料を反故汅しないように私達も協力しょう という嬉しい申し出もあった。

しかし, あれから15年の歳月がたち, 振り返っ てみると歯科医療費についての改善は遅々として 進まず，何ともやるせない淋しい気持の連続であ った. 折しも先日, NHK テレビがドキュメント 番組を組み，総義歯の価格をテーマとしてとりあ げ放映した。私は，過去ほぼ20年にわたって，歯 科医療費について，あらゆるところで，あらゆる 機会に，適正な報酬を，と訴えつづけてきたが， 最近これがいくらかでも世人の口にのぼるよらに なったことは嬉しい限りである。

今回は，日本顎咬合学会のご好意により，私の 年来の主張が学会誌上に掲載されることになり, まことに光栄に存じ，かつ，感謝に耐えない次第 である。 